\title{
Cloning of a Gene Cluster of aroB, aroE and aroL for Aromatic Amino Acid Biosynthesis in Brevibacterium lactofermentum, a Glutamic Acid-producing Bacterium
}

\author{
Kazuhiko Matsui, Kiyoshi Miwa and Konosuke Sano \\ Central Research Laboratories, Ajinomoto Co., Ltd., \\ Kawasaki-ku, Kawasaki 210, Japan \\ Received September 10, 1987
}

\begin{abstract}
The aroL gene, encoding shikimate kinase of Brevibacterium lactofermentum, a coryneform glutamic acid-producing bacterium, was cloned. Recombinant plasmids containing the aro $L$ gene caused elevated levels of shikimate kinase synthesis in $B$. lactofermentum. It was found that in addition to the aro $L$ gene, the $a r o B$ and aro $E$ genes, encoding dehydroquinate synthase and shikimate dehydrogenase, respectively, also existed on these recombinant plasmids, in complementation tests with various Escherichia coli and B. lactofermentum aromatic amino acid auxotrophs. The aroL, aro $B$ and $a r o E$ genes of $B$. lactofermentum are located closely on the cloned DNA fragment, in that order. It was shown that at least these three aro genes form a cluster on the chromosome of B. lactofermentum.
\end{abstract}

Brevibacterium lactofermentum is an industrially important Gram-positive bacterium used for the production of various amino acids. We have focused our attention on the aromatic amino aicd biosynthesis of this microorganism, because phenylalanine is important as a component of "Aspartame", a sweettasting peptide, and tryptophan as an ingredient of medicines and animal feeds.

The pathway for the biosynthesis of aromatic amino acid in this organism is shown in Fig. 1. The enzyme for the first step of the common pathway, 3-deoxy-D-arabinoheptulosonate 7-phosphate (DAHP) synthetase, in B. lactofermentum and B. flavum was investigated biochemically. ${ }^{1}$ It was synergistically inhibited by both phenylalanine and tyrosine, and repressed by tyrosine. Furthermore, DAHP synthetase in most $m$ fluorophenylalanine resistant mutants was genetically desensitized to this synergistic inhibition. ${ }^{2)}$ Ito et al. have already cloned the gene encoding DAHP synthetase of the $\mathrm{m}$ - fluorophenylalanine resistant mutant, $B$. lactofermentum AJ11957, and analyzed the effect of the clone on aromatic amino acid production. ${ }^{3)}$ However, the natures of the enzymes and genes in this common pathway in $B$. lactofermentum have not been investigated in detail except for DAHP synthetase.

In Escherichia coli, it is known that there are three types of DAHP synthetases ${ }^{4)}$ and two types of shikimate kinases ${ }^{5)}$ (Fig. 1). The tyr $R$ gene product controls the expression of DAHP synthetases encoded by aro $F$ and $\operatorname{aro} G$, and shikimate kinase II encoded by aroL. ${ }^{6,7)}$ DAHP synthetase encoded by aroH is under the control of the $\operatorname{tr} p R$ gene. ${ }^{8)}$ Shikimate kinase I and the other enzymes in the common pathway are synthesized constitutively except for DAHP synthetases and shikimate kinase II. ${ }^{9)}$

In Bacillus subtilis, the synthesis of shikimate kinase is controlled by $t y r R$, and inhibited as a part of the regulatory trifunctional enzyme complex (DAHP synthetase, choris-

Abbreviations: Ap, ampicillin; $\mathrm{Cm}$, chloramphenicol; $\mathrm{Cm}^{\mathrm{r}}$, chloramphenicol resistance; DAHP synthetase, 3deoxy-D-arabino-heptulosonate 7-phosphate synthetase. 
mate mutase and shikimate kinase) by prephenate and chorismate. ${ }^{10)}$

Recently, it was reported that the synthesis
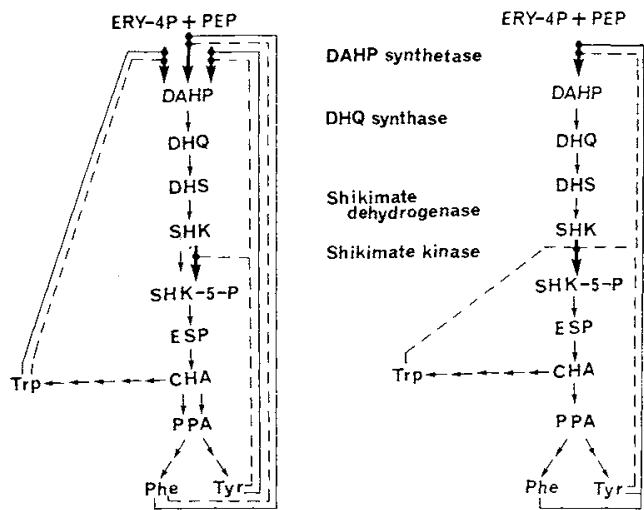

Fig. 1. Pathway for Aromatic Amino Acid Biosynthesis. In the common pathway, thick arrows indicate the enzymes regulated through repression or feedback inhibition. Dotted lines and thin lines indicate repression and feedback inhibition, respectively. Abbreviations: PEP, phosphoenolpyruvate; ERY-4P, erythrose-4-phosphate; DHQ, dehydroquinate; DHS, dehydroshikimate; SHK, shikimate; SHK-5-P, shikimate-5-phosphate; ESP, 3-enolpyruvyl shikimate 5-phosphate; CHA, chorismate; PPA, prephenate. of shikimate kinase in $B$. lactofermentum was repressed by tyrosine and tryptophan. Thus, shikimate kinase may also play a role as the control step in the common pathway as well as DAHP synthetases in various kinds of $\mathrm{mi}$ croorganisms. Furthermore, it has been reported that in $E$. coli mutants with unregulated DAHP synthetases, dehydroquinate synthase becomes rate-limiting for carbon flow through the common pathway. ${ }^{11)}$

We have developed a host-vector system for B. lactofermentum, ${ }^{12)}$ and have been using it successfully for gene cloning and for improvement of various amino acid productivities. ${ }^{13 \sim 15)}$ To investigate the structures and regulation mechanisms of the $B$. lactofermentum aro genes and to improve the aromatic amino acid productivities, we have cloned the aro $L$ gene encoding shikimate kinase of a wild type strain, B. lactofermentum AJ12036. Furthermore, we have found the aroB and aroE genes, endoding dehydroquinate synthase and shikimate dehydrogenase, respectively, on the recombinant plasmids containing the aro $L$ gene.

Table I. Bacterial Strains Employed in This Study

\begin{tabular}{|c|c|c|}
\hline Strain & Genotype & Remarks \\
\hline $\begin{array}{l}\text { B. lactofermentum AJ12036 } \\
\text { derivatives of AJ12036 }\end{array}$ & Prototroph & \\
\hline AJ 12157 & aroL & Shikimate kinase deficient \\
\hline No. 32 & $\operatorname{aroE}$ & Shikimate dehydrogenase deficient \\
\hline E. coli $\mathrm{AB} 3257$ & $\begin{array}{l}\text { thi- } 1, \text { ilvC7, arg } E 3, \text { his- } 4, \text { pro } A 2, \\
\text { aroH } 367, \text { aroG } 365, \text { aro } 363, x y l-5, \\
\text { galK2, lac } Y 1, \text { mtl-1, strA712, tfr-3, } \\
\text { tsx-358, supE } 44\end{array}$ & $\begin{array}{l}\text { Obtained from } E \text {. coli Genetic } \\
\text { Stock Center, U.S.A. }\end{array}$ \\
\hline $\mathrm{AB} 2847$ & $\begin{array}{l}\operatorname{aroB351}, \operatorname{tsx}-354, \mathrm{mal}-354, \lambda^{\mathrm{R}}, \lambda^{-} \\
\operatorname{supE42}\end{array}$ & $\begin{array}{l}\text { Obtained from } E \text {. coli Genetic } \\
\text { Stock Center, U.S.A. }\end{array}$ \\
\hline AB2849 & aroC353, tsx-357, sup E42, $\hat{\lambda}^{-}$ & $\begin{array}{l}\text { Obtained from } E \text {. coli Genetic } \\
\text { Stock Center, U.S.A. }\end{array}$ \\
\hline $\mathrm{AB} 2848$ & $\operatorname{aroD} 352, \operatorname{ts} x-356, \sup E 42, \lambda^{-}$ & $\begin{array}{l}\text { Obtained from } E \text {. coli Genetic } \\
\text { Stock Center, U.S.A. }\end{array}$ \\
\hline $\mathrm{AB} 2834$ & $\begin{array}{l}\operatorname{aro} E 353, \text { mal352, ts } x-352, \lambda^{\mathrm{R}}, \hat{\lambda}^{-} \\
\sup E 42\end{array}$ & $\begin{array}{l}\text { Obtained from E. coli Genetic } \\
\text { Stock Center, U.S.A. }\end{array}$ \\
\hline $\mathrm{AB} 2829$ & $\operatorname{aro} A 354, \hat{\lambda}^{-}, \sup E 42$ & $\begin{array}{l}\text { Obtained from E. coli Genetic } \\
\text { Stock Center, U.S.A. }\end{array}$ \\
\hline HB101 & $\begin{array}{l}\mathrm{F}^{-}, \text {hsdS20 }\left(\mathrm{r}_{\mathrm{B}}^{-}, \mathrm{m}_{\mathrm{B}}^{-}\right), \operatorname{rec} A 13, \\
\operatorname{ara}-14, \operatorname{pro} A 2, \operatorname{lac} Y 1, \operatorname{galK} 2, \lambda^{-} \\
x y l-5, \operatorname{mil}-1, \sup E 44, \operatorname{rpsL} 20\left(\mathrm{Sm}^{\mathrm{r}}\right)\end{array}$ & Reference 26 ) \\
\hline
\end{tabular}

The $B$. lactofermentum gene designations follow the $E$. coli nomenclature. 


\section{MATERIALS AND METHODS}

Bacterial strains and plasmids. The bacterial strains used in this study are listed in Table I. A wild type strain of $B$. lactofermentum, $\mathrm{AJ} 12036,{ }^{12)}$ was used as the DNA donor for gene cloning. Aromatic amino acid auxotrophs, $B$. lactofermentum $\mathrm{AJ} 12157$ (aroL) and No. 32 (aroE), were isolated from AJ12036 through $N$-methyl- $N^{\prime}$-nitro- $N$ nitrosoguanidine treatment, and used for cloning and complementation tests.

A shuttle vector between $E$. coli and B. lactofermentum, $\mathrm{pAJ} 1844,{ }^{12 l}$ was used for cloning of the $B$. lactofermentum aro genes. Plasmids pAJ43 $\left(\mathrm{Cm}^{\mathrm{r}}\right)^{12)}$ and pUC8 $\left(\mathrm{Ap}^{\mathrm{r}}\right)^{16}$ were used for subcloning of each aro gene in $B$. lactofermentum and E. coli, respectively.

Media. Compelete medium $\mathrm{CM} 2 \mathrm{G}^{17)}$, Medium $31^{18)}$ and minimal medium $\mathrm{MBM}^{17)}$ were used for the cultivation of $B$. lactofermentum. For regeneration of protoplasts of $B$. lactofermentum, medium $\mathrm{RB}^{12)}$ was employed and $\mathrm{Cm}$ was added at $3 \mu \mathrm{g} / \mathrm{ml}$, if necessary.

Davis's minimal medium ${ }^{19}$ and Luria-Bertani broth ${ }^{20)}$ were used for the cultivation of $E$. coli.

DNA isolation and recombinant plasmid construction. Total DNA of B. lactofermentum AJ12036 was isolated as described previously. ${ }^{21}$ Plasmid DNAs were prepared by the slightly modified EtBr-CsCl density gradient method. ${ }^{22)}$ Restriction enzymes and T4-DNA ligase were purchased from Takara and used under the conditions recommended by the supplier.

Transformation. The protoplast transformation method was employed for B. lactofermentum. ${ }^{12}$ Transformation of E. coli was carried out as described previously. ${ }^{23)}$

Preparation of cell extracts. Cells of $B$. lactofermentum were cultured in $500 \mathrm{ml}$-flasks containing $20 \mathrm{ml}$ of Medium 31 at $30^{\circ} \mathrm{C}$ for $22 \mathrm{hr}$, harvested, washed twice with $0.2 \% \mathrm{KCl}$ and then suspended in $0.1 \mathrm{M} \mathrm{Tris}-\mathrm{HCl}$ buffer $(\mathrm{pH} 7.4)$. Then, the cells were disrupted by sonication $(50 \mathrm{~W}, 8 \mathrm{~min})$. The crude extract, obtained as the supernatant after cenrifugation at $32,000 \times g$ for $20 \mathrm{~min}$, was assayed immediately for enzyme activity.

For E. coli, cells were cultured in $500 \mathrm{ml}$-flasks containing $100 \mathrm{ml}$ of Luria-Bertani broth at $37^{\circ} \mathrm{C}$ for $17 \mathrm{hr}$, harvested, washed twice with $0.9 \% \mathrm{NaCl}$ and then suspended in $0.1 \mathrm{~m}$ Tris- $\mathrm{HCl}$ buffer $(\mathrm{pH} \mathrm{7.4)}$. The cells were disrupted by sonication ( $50 \mathrm{~W}, 3 \mathrm{~min}$ ) and then centrifuged at $32,000 \times g$ for $20 \mathrm{~min}$. The resulting crude extract was used for the enzyme assay.

Assaying of shikimate kinase activity. The incubation mixture contained $1 \mathrm{~mm}$ shikimate, $4 \mathrm{~mm}$ ATP, $5 \mathrm{~mm}$ $\mathrm{MgCl}_{2}, 10 \mathrm{~mm} \mathrm{NaF}, 50 \mathrm{~mm}$ Veronal buffer (pH 9.0) and crude cell extract ( 0.1 to $1.0 \mathrm{mg}$ of protein) in a total volume of $1.0 \mathrm{ml}$. Incubation was carried out at $30^{\circ} \mathrm{C}$ for
$30 \mathrm{~min}$. Then, $0.2 \mathrm{ml}$ of $1 \mathrm{M}$ Tris- $\mathrm{HCl}$ buffer ( $\mathrm{pH} \mathrm{7.8)} \mathrm{was}$ added, and the mixture was boiled for $2 \mathrm{~min}$ and then chilled on ice. Kinase activity was determined by measuring the disappearance of shikimate according to the method of Gaitonde and Gordon. ${ }^{24)}$

Assaying of shikimate dehydrogenase activity. The method described by Yaniv and Gilvarg ${ }^{25)}$ was used. The reaction was started by adding $2 \mathrm{mM}$ shikimate to $0.1 \mathrm{M}$ Tris- $\mathrm{HCl}$ buffer ( $\mathrm{pH} 8.0), 0.2 \mathrm{mM}$ NADP and enzyme $(0.05$ to $0.4 \mathrm{mg}$ of protein) in a final volume of $1 \mathrm{ml}$. After rapid mixing, the change in absorbance at $340 \mu \mathrm{m}$ of NADPH was measured for $3 \mathrm{~min}$ at room temperature.

Analysis of the copy numbers of the recombinant plasmids. The copy numbers of recombinant plasmids in $B$. lactofermentum were determined by the agarose gel electrophoresis method. ${ }^{22)}$

\section{RESULTS}

Cloning of the aroL gene encoding the shikimate kinase of $B$. lactofermentum

Chromosomal DNA of $B$. lactofermentum AJ12036 and plasmid vector pAJ1844 was digested with PstI partially and completely, respectively. They were mixed and ligated with T4-DNA ligase, and then the ligated DNA was used to transform shikimate kinase deficient mutant AJ12157 (aroL) which requires aromatic amino acid for growth. After incubation on regeneration medium $\mathrm{RB}$ supplemented with $3 \mu \mathrm{g} / \mathrm{ml}$ of $\mathrm{Cm}$ at $30^{\circ} \mathrm{C}$ for 10 days, about 3,800 regenerated $\mathrm{Cm}^{\mathrm{r}}$ colonies were transferred by the replica method to minimal medium MBM. Five transformants were found to grow on MBM. From these transformants, plasmid DNAs were extracted, and designated at

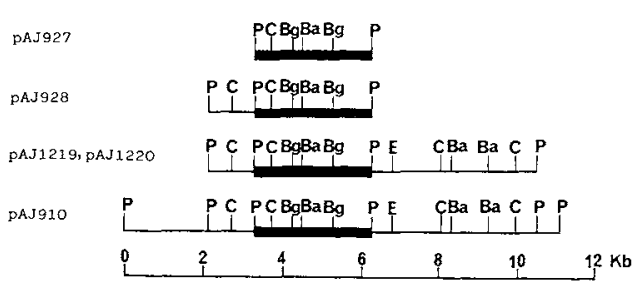

FIG. 2. Restriction Enzyme Cleavage Maps of Inserts on Different Recombinant Plasmids.

Black segments indicate the common $2.9 \mathrm{~kb}$ Pst I fragment in the inserts. Abbreviations: $\mathrm{Ba}, B a m \mathrm{HI} ; \mathrm{Bg}, B g l \mathrm{II} ; \mathrm{C}$, ClaI; E, Eco RI; P, PstI. 
pAJ910, pAJ927, pAJ928, pAJ1219 and pAJ1220, respectively. These plasmids were used for re-transformation of $\mathrm{AJ} 12157$, and it was confirmed that all of them could complement AJ12157. Restriction enzyme cleavage maps of the inserts of these plasmids are shown in Fig. 2. When these plasmids were digested with $P_{s t} \mathrm{I}$, all were found to contain a common $2.9 \mathrm{~kb}$ Pst I fragment. Therefore, it was considered that the aroL gene encoding shikimate kinase existed on this $2.9 \mathrm{~kb}$ Pst fragment.

Shikimate kinase activities of strains harboring recombinant plasmids containing the aroL gene

The presence of recombinant plasmids containing the aro $L$ gene caused elevated levels of shikimate kinase activity in B. lactofermentum. The transformed strains had $14 \sim 18$ copies of the recombinant plasmids and exhibited approximately 10 times higher shikimate kinase activity than that of $B$. lactofermentum AJ12036 (Table II).

Identification of the aro $B$ and aro $E$ genes on recombinant plasmids containing the aroL gene

To determine whether other aro geres existed on recombinant plasmids containing the aroL gene or not, each plasmid was introduced into various aro mutants of $E$. coli. All of the recombinant plasmids were able

Table II. Plasmid Copy Number and Shikimate Kinase Activity

\begin{tabular}{ccc} 
Copy & $\begin{array}{c}\text { Specific activity } \\
\text { (nmol } / \mathrm{min} / \mathrm{mg} \\
\text { protein) }\end{array}$ \\
\hline
\end{tabular}

B. lactofermentum
AJ12036
B. lactofermentum
AJ12157

- , not determined. to complement an $E$. coli dehydroquinate synthase deficient mutant, AB2847 (aro B351). Furthermore, pAJ910 and pAJ1219 (pAJ1220) were also able to complement shikimate dehydrogenase deficient mutants, E. coli AB2834 (aroE353) and B. lactofermentum No. 32 (aroE). It appeared that both pAJ927 and pAJ928 harbored the aro $L$ and aro $B$ genes, and that on pAJ910 and pAJ1219 (pAJ1220), the $\operatorname{aro} L, \operatorname{aro} B$ and aro $E$ genes existed.

Shikimate dehydrogenase activities of strains harboring recombinant plasmids containing the aroE gene

Table III shows shikimate dehydrogenase activities in $E$. coli. The presence of plasmids containing the $B$. lactofermentum aro $E$ gene in E. coli AB2834 (aroE353) caused levels of shikimate dehydrogenase activity that were about 3-fold higher than that of $E$. coli $\mathrm{HB} 101$ $\left(a r o E^{+}\right){ }^{26)}$. On the other hand, the specific activities of shikimate dehydrogenase of $B$. lactofermentum $\mathrm{AJ} 12157$ harboring these plasmids exhibited levels that were about 2-fold higher than that of $B$. lactofermentum AJ 12036 (data not shown). The degree of elevation of the enzyme activity was lower than that predicted on the basis of the case of shikimate kinase.

Subcloning and localization of aro genes on recombinant plasmids

The results of complementation tests and restriction enzyme cleavage maps of inserts showed that the aro $L$ and $\operatorname{aro} B$ genes existed on the $2.9 \mathrm{~kb}$ Pst I fragment (Figs. 2 and 3). To subclone each of the aro $L$ and $a r o B$ genes (Fig.

Table III. Shikimate Dehydrogenase Activity

\begin{tabular}{lc}
\hline Strain & $\begin{array}{c}\text { Specific activity } \\
\text { (nmol/min/mg protein) }\end{array}$ \\
\hline E. coli & \\
HB101 & 5.6 \\
AB2834 & 0 \\
AB2834/pAJ927 & 0 \\
AB2834/pAJ1219 & 16.3 \\
AB2834/pAJ910 & 14.4
\end{tabular}




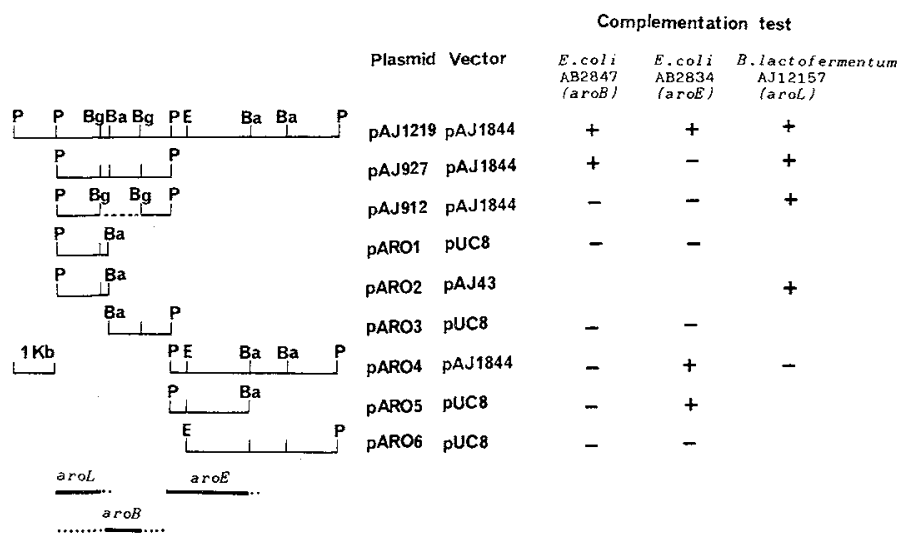

FIG. 3. Localization of the B. lactofermentum aro Genes on Cloned DNA Fragments.

Restriction enzyme cleavage maps of the subcloned DNA fragments and the results of complementation tests are shown. The dotted line in the restriction map for pAJ912 indicates the deleted region. The results of complementation tests are: + (growth) and - (no growth). The most probable location of each aro gene on the cloned DNA fragments is shown at the bottom of the figure. Abbreviations: $\mathrm{Ba}, B a m \mathrm{HI} ; \mathrm{Bg}, B g / \mathrm{II} ; \mathrm{E}, E c o \mathrm{RI}$; P, PstI.

3 ), we at first constructed pAJ912, which has a deletion of $1.0 \mathrm{~kb} B g / \mathrm{II}$ fragment within the $2.9 \mathrm{~kb}$ Pst I fragment on pAJ927. pAJ912 was able to complement $B$. lactofermentum $\mathrm{AJ} 12157$ (aroL), but not E. coli AB2847 (aroB35l). Then, the $1.3 \mathrm{~kb}$ PstI-BamHI fragment within the $2.9 \mathrm{~kb}$ PstI fragment was subcloned onto E. coli plasmid pUC8. The resulting plasmid, pARO1, was not able to complement E. coli AB2847 (aroB351). Since pAROI could not replicate in $B$. lactofermentum, pARO1 was digested with BamHI and then cloned on $\mathrm{pAJ} 43$, a vector for B. lactofermentum. Thus, the constructed plasmid, pARO2, could complement AJ12157. Another Pst I-BamHI fragment $(1.6 \mathrm{~kg})$ within the $2.9 \mathrm{~kb}$ Pst I fragment was also subcloned on pUC8, but the resulting plasmid, pARO3, could not complement E. coli AB2847.

On the other hand, it was suggested that the aro $E$ gene is located on the $4.3 \mathrm{~kb} P s t \mathrm{I}$ fragment of pAJ1219 and pAJ910 (Figs. 2 and 3). To determine the location of the aro $E$ gene, at first the $4.3 \mathrm{~kb}$ PstI fragment of pAJ1219 was subcloned on pAJ1844. The resulting plasmid, pARO4, could complement E. coli AB2834 (aroE353) and caused the same level of shikimate dehydrogenase activity as pAJ1219 in
$\mathrm{AB} 2834$. Then, a $2.0 \mathrm{~kb}$ Pst $\mathrm{I}-$ Bam $\mathrm{HI}$ fragment and a $3.9 \mathrm{~kb} E c o$ RI-PstI fragment were prepared from the $4.3 \mathrm{~kb}$ Pst I fragment, ligated to pUC8 and then used to transform E. coli AB2834 (aroE353), respectively. The resultant recombinant plasmid, pARO5, containing the former fragment was able to complement $E$. coli $\mathrm{AB} 2834$, but the plasmid, pARO6, containing the latter fragment could not.

According to these results, the aroB, aroE and aro $L$ genes existing on the inserts of the recombinant plasmids were localized as shown at the bottom of Fig. 3, respectively. It appeared that these three aro genes were located close to each other.

\section{DISCUSSION}

The aro $L$ gene encoding shikimate kinase of $B$. lactofermentum was cloned. All of the recombinant plasmids isolated independently contained a common $2.9 \mathrm{~kb}$ Pst I fragment, and caused elevated levels of shikimate kinase activities in B. lactofermentum. In complementation tests, we have found that the $\operatorname{aro} B$ and aro $E$ genes encoding dehydroquinate synthase and shikimate dehydrogenase, respectively, also existed on recombinant plasmids contain- 
ing the aro $L$ gene. Both the $a r o B$ and aro $L$ genes were localized on the cloned $2.9 \mathrm{~kb}$ Pst fragment, and the aro $E$ gene was localized on the cloned $4.3 \mathrm{~kb}$ Pst I fragment, and the $a r o L$, aro $B$ and aro $E$ genes existed close to each other on the inserts, in that order. The present results show that in $B$. lactofermentum, a Gram-positive bacterium, these three aro genes form a cluster on its chromosome.

In $E$. coli ${ }^{27)}$ and $S$. typhimurium, ${ }^{28)}$ the aro genes of the common pathway are scattered over their chromosomes. In B. subtilis, it was reported that the genes for dehydroquinate synthase, 3-enolpyruvyl shikimate 5-phosphate synthetase and one form of chorismate mutase are closely linked. ${ }^{29)}$ However, the genes for dehydroquinate synthase, shikimate kinase and shikimate dehydrogenase are scattered over its chromosome. ${ }^{30)}$ In contrast to the cases in these bacteria, the five central enzymes (the second through sixth enzymes) of the common pathway in Neurospora crassa, ${ }^{31}$ Euglena $^{32)}$ and Saccharomyces pombe ${ }^{33)}$ are encoded by the arom gene cluster, which specifies a pentafunctional enzyme on a single polypeptide chain.

Recently, Defeyter and Pittard cloned the aro $L$ gene encoding shikimate kinase II of $E$. coli, and determined the nucleotide sequence of the cloned DNA fragment. ${ }^{34,35)}$ They identified the aro $M$ gene that was cotranscribed with aroL, and this aro $L M$ operon was subjected to repression control by $t y r R$. The aro $M$ gene encodes a 26 kilodalton gene product of unknown function. In B. lactofermentum, the synthesis of shikimate kinase is repressed by tyrosine. Therefore, there is a possibility that these aro $L$, aro $B$ and aro $E$ genes may act as an operon, but we have no genetic evidence at present. Furthermore, there is another possibility that the cloned aroL gene encodes a bifunctional polypeptide consisting of a shikimate kinase domain (aroL domain) and a dehydroquinate synthase domain (aroB domain).

The organization of the $B$. lactofermentum trp operon, and the structure and function of the control regions for expression of its trp genes closely resemble those of $E$. coli. ${ }^{36,37)}$ This is interesting in view of taxonomy, because $B$. lactofermentum is a Gram-positive bacterium whereas $E$. coli is a Gram-negative organism. Since the cloned aro genes of $B$. lactofermentum were expressed in $E$. coli as well as in the case of trp genes, ${ }^{38)}$ the gene expression mechanisms in $B$. lactofermentum seem to resemble those in $E$. coli generally. However, the distribution and organization of these aro genes on the chromosome are quite different from those in $E$. coli in contrast with in the case of the trp operon, and resemble those in lower eukaryotes.

The presence of recombinant plasmids containing the aro $L$ gene caused elevated levels of shikimate kinase in $B$. lactofermentum. These changes in enzyme levels (approximately 10fold) seem to reflect the copy numbers of recombinant plasmids. Howerer, in the case of shikimate dehydrogenase, the elevation of the activity (approximately 2 -fold) was lower than that of shikimate kinase activity, although both the aroE and aro $L$ genes existed on the same plasmid. There are no available data to explain this observation.

To improve the tryptophan productivity, we have been introducing these plasmids into a tryptophan producer. Our preliminary results showed that the amplification of these genes was effective for the breeding of tryptophan producer. ${ }^{39)}$ Sato et al. have also successfully improved the productivities of phenylalanine and tyrosine by introducing a recombinant plasmid containing the aro $B$ and aro $L$ genes of B. lactofermentum AJ11957 into such amino acid producers. ${ }^{40)}$

\section{REFERENCES}

1) I. Shiio, S. Sugimoto and R. Miyajima, J. Biochem., 75, 987 (1974).

2) S. Sugimoto, M. Nakagawa, T. Tsuchida and I. Shiio, Agric. Biol. Chem., 37, 2327 (1973).

3) K. Sato, H. Ito, K. Matsui, K. Miwa, K. Sano, T. Tanaka, S. Nakamori and H. Enei, Abstracts of Papers, the Annual Meeting of the Society of Fermentation Technology, Japan, Tokyo, October, 1985 , p. 123.

4) C. H. Doy and K. D. Brown, Biochim, Biophys. Acta, 
104, 377 (1965).

5) M. B. Berlyn and N. H. Giles, J. Bacteriol., 99, 222 (1969).

6) K. D. Brown and R. L. Somerville, J. Bacteriol., 108, 386 (1971).

7) B. Ely and J. Pittard, J. Bacteriol., 138, 933 (1979).

8) J. Pittard, J. Camakaris and B. J. Wallace, J. Bacteriol., 97, 1242 (1969).

9) D. E. Tribe, H. Camakaris and J. Pittard, J. Bacteriol., 127, 1085 (1976).

10) E. W. Nester, J. H. Lorence and D. S. Nasser, Biochemistry, 6, 1553 (1967).

11) T. Ogino, C. Garner and D. J. Markley, Proc. Natl. Acad. Sci. U.S.A., 79, 5828 (1982).

12) K. Miwa, K. Matsui, M. Terabe, K. Ito, M. Ishida, H. Takagi, S. Nakamori and K. Sano, Gene, 39, 281 (1985).

13) S. Nakamori, M. Ishida, H. Takagi, K. Ito, K. Miwa and K. Sano, Agric. Biol. Chem., 51, 87 (1987).

14) Y. Morinaga, H. Takagi, M. Ishida, K. Miwa, T. Sato, S. Nakamori and K. Sano, Agric. Biol. Chem., 51, 93 (1987)

15) K. Sano, K. Ito, K. Miwa and S. Nakamori, Agric. Biol. Chem., 51, 597 (1987).

16) J. Vieira and J. Messing, Gene, 19, 259 (1982).

17) K. Sano and I. Shiio, J. Gen. Appl. Microbiol., 13, 349 (1967).

18) S. Sugimoto and I. Shiio, Agric. Biol. Chem., 46, 2711 (1982)

19) B. D. Davis and E. S. Mingiolli, J. Bacteriol., 60, 17 (1950).

20) J. Miller, "Experiments in Molecular Genetics," Cold Spring Harbor Laboratory, Cold Spring Harbor, New York, 1972, p. 433.

21) H. Saito and K. Miura, Biochim. Biophys. Acta, 72, 619 (1963).

22) K. Miwa, H. Matsui, M. Terabe, S. Nakamori, K. Sano and H. Momose; Agric. Biol. Chem., 48, 2901 (1984).
23) M. Mandel and A. Higa, J. Mol. Biol., 53, 159 (1970).

24) M. H. Gaitonde and M. W. Gordon, J. Biol. Chem., 230, 1043 (1958).

25) H. Yaniv and C. Gilvarg, J. Biol. Chem., 213, 787 (1955).

26) F. Bolivar and K. Backman, Methods Enzymol., 68 , 245 (1979).

27) J. Pittard and B. J. Wallace, J. Bacteriol, 91, 1494 (1966).

28) Y. Nishioka, M. Demerec and A. Eisenstark, Genetics, 56, 341 (1967).

29) F. Gibson and J. Pittard, Bacteriol. 'Reviews, 32, 465 (1968).

30) D. J. Henner and J. A. Hoch, Microbiol. Reviews, 44, 57 (1980).

31) N. H. Giles, M. E. Case, C. W. H. Partridge and S. I. Ahmed, Proc. Natl. Acad. Sci. U.S.A., 58, 1453 (1967).

32) M. B. Berlyn, S. I. Ahmed and N. H. Giles, J. Bacteriol., 104, 768 (1970).

33) A. Strauss, Mol. Gen. Genet., 172, 233 (1979).

34) R. C. Defeyter and J. Pittard, J. Bacteriol., 165, 226 (1986).

35) R. C. Defeyter, B. E. Davidson and J. Pittard, J. Bacteriol., 165, 233 (1986).

36) K. Matsui, K. Sano and E. Ohtsubo, Nucl. Acids Res., 14, 10113 (1986).

37) K. Sano and K. Matsui, Gene, 53, 191 (1987).

38) K. Matsui, K. Miwa and K. Sano, Agric. Biol. Chem., 51, 823 (1987).

39) K. Matsui, K. Miwa and K. Sano, Abstracts of Papers, the Annual Meeting of the Society of Fermentation Technology, Japan, Tokyo, October, 1985, p. 34.

40) K. Sato, H. Ito, K. Matsui, K. Sano and H. Enei, Abstracts of Papers, the Annual Meeting of the Agricultural Chemical Society of Japan, Kyoto, April, 1986, p. 299. 